\title{
Closed-loop speed control of switched reluctance motor drive fed from novel converter with reduced number of switches
}

\author{
Ashok Kumar Kolluru, Malligunta Kiran Kumar \\ Department of Electrical and Electronics Engineering, Koneru Lakshmaiah Education Foundation, India
}

\begin{tabular}{|c|c|}
\hline Article Info & ABSTRACT \\
\hline Article history: & \multirow{9}{*}{$\begin{array}{l}\text { The paper presents a novel converter configuration with fewer for switched } \\
\text { reluctance motor (SRM) drive. The proposed novel converter insists for less } \\
\text { number of switches compared to conventional asymmetrical type of } \\
\text { converter configuration for switched reluctance motor. Switch count } \\
\text { reduction in converter reduces the losses, volume of heat sink, and number of } \\
\text { gate drive circuits and thereby the performance of the system. Closed loop } \\
\text { speed control of switched reluctance motor fed from proposed novel } \\
\text { converter topology was presented in this paper. Performance of closed loop } \\
\text { operation is compared to open loop system. Further the proposed converter } \\
\text { for SRMT is evaluated with loaded condition and comparative analysis of } \\
\text { no-load and loaded SRM is presented. The model presented is developed and } \\
\text { the results are analyzed using MATLAB/SIMULINK software. Closed loop } \\
\text { performance of proposed novel converter fed switched reluctance motor } \\
\text { drive is verified at fixed speed and variable speed conditions. }\end{array}$} \\
\hline ReceivedApr 4, 2019 & \\
\hline Revised Jul 8, 2019 & \\
\hline Accepted Nov 10, 2019 & \\
\hline Keywords: & \\
\hline Closed loop & \\
\hline Control & \\
\hline Speed & \\
\hline $\begin{array}{l}\text { Switched reluctance } \\
\text { motorConverter for SRM }\end{array}$ & \\
\hline
\end{tabular}

This is an open access article under the CC BY-SA license.

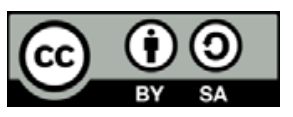

\section{Corresponding Author:}

Ashok Kumar Kolluru,

Department of Electrical and Electronics Engineering,

KoneruLakshmaiah Education Foundation,

Guntur-522502, Andhra Pradesh, India.

Email: kolluruashok206@gmail.com

\section{INTRODUCTION}

Switched reluctance motor (SRM) is a special electrical machine in modern day electrical applications due to its superior merits over other type of electrical machines. SRM basically operates on the principle of reluctance torque which is responsible for the rotation of rotor [1-7]. Simple construction over other conventional electrical machines makes SRM the preferred machine. Switched reluctance machine is a doubly salient pole machine in which stator and rotor as well consists of salient poles. Coils are wounded on stator poles and rotor is just a simple ferro-magnetic salient material. Rotor of switched reluctance motor consists of neither coils nor permanent magnets. High reliability and low cost make SRM very much applicable to many of the applications [8-11].

SRM, these days is a predominant option as a motor used in adjustable speed drive system with minimum cost and high reliability. Due to non-existence of windings on rotor, weight of the rotor part decreases and as a result rotor can rotate at high speeds. SRM finds the applications in high speed drives [12-15]. Owing to further inherent advantages like high efficiency, high reliability, excellent fault-tolerance, and high starting torque in initial accelerations, SRMs are preferred to be a competitive to other type of special application electrical machines [16-20]. Switched reluctance motor requires sensors for its position sensing but intensive research in SRM, made sensorless speed control possible. Requirement of sensors for position sensing, acoustic noise are disadvantages of SRM. Apart from these two, the main disadvantage in 
SRM includes high torque ripples. Though the usage of SRM in industries is less, SRM can achieve relatively high speds compared to othr motors.

The important point where SRM stands high is its control circuit tunes the torque-speed characteristics [20-27]. SRM is limited with its operation in point of sourc voltage and temperature ris with increased loads. Figure 1 illustrates the basic block diagram of switched reluctance motor which essentially consists of a source for excitation, converter for phase switching of coils, sensing unit for position sensing and a controller to control the parameters and to produce pulses for switches in converter. The controller after producing pulses; converter switches commutes the pair of poles by exciting the stator coils of SRM.

The paper presents a novel converter configuration with less number of switches for switched reluctance motor (SRM) drive. The proposed novel converter insists for less number of switches compared to conventional asymmetrical type of converter configuration for switched reluctance motor. Closed loop speed control of switched reluctance motor fed from proposed novel converter topology was presented in this paper. Performance of closed loop operation is compared to open loop system. The model presented is developed and the results are analyzed using MATLAB/SIMULINK software. Closed loop performance of proposed novel converter fed switched reluctance motor drive is verified at fixed speed and variable speed conditions.

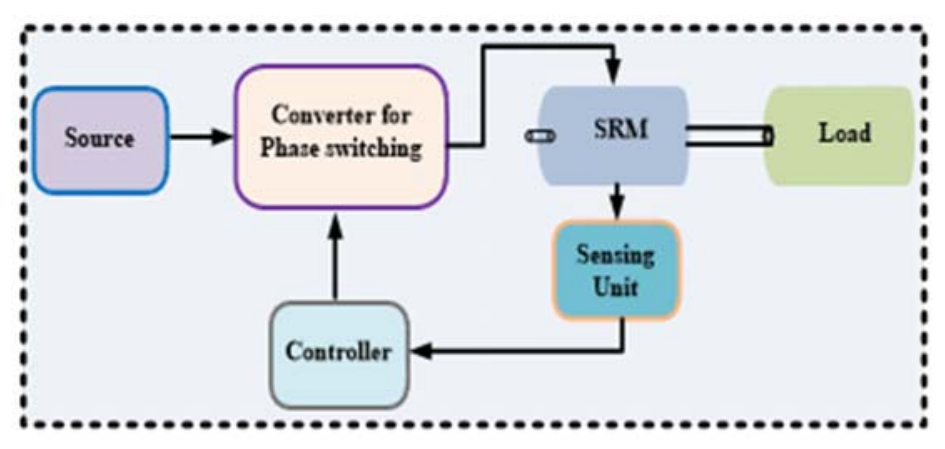

Figure 1. Basic diagram of switched reluctance motor

\section{PROPOSED NOVEL CONVERTER FOR SWITCHED RELUCTANCE MOTOR}

\subsection{Proposed converter topology}

The proposed novel converter topology for switched reluctance motor is shown in Figure 2. The proposed converter is developed to switch the phases of switched reluctance motor with components like four power semiconductor switches (S1 to S4) and four diodes (D1 to D4). The converter is excited from a DC source. Wherein, a conventional asymmetrical converter for SRM consists of six power switches and six diodes for switching the phases of SRM. With reduction in usage of power switches and diodes, the number of gate drivers required becomes less, heat sink requirement will be less and as a result switching loss gets reduced.

Comparative analysis of proposed converter with asymmetrical converter was depicted in Table 1. It shows that the number of power switches in proposed converter is less compared to asymmetrical converter. Number of diodes requirement in proposed converter is less than asymmetrical converter. As numbers of components are reduced switching losses are less in proposed converter. Heat sink requirement is also less comparatively since only four switches are used. Numbers of gate drivers are also reduced in proposed converter.

Table 1.Comparative analysis of proposed converter and asymmetrical converter

\begin{tabular}{ccc}
\hline Component & Proposed Converter & Asymmetrical Converter \\
\hline Number of power switches & 4 & 6 \\
Number of diodes & 4 & 6 \\
Switching losses & Comparatively Low & High \\
Number of gate drivers & 4 & 6 \\
Heat sink volume & Low & High \\
\hline
\end{tabular}

Int J Pow Elec \& Dri Syst Vol. 11, No. 1, Mar $2020: 189$ - 199 


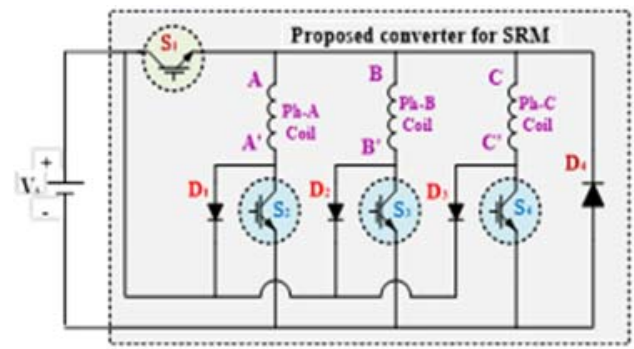

Figure 2. Circuit representation of proposed novel converter for switched reluctance motor

\subsection{Modes of operation of proposed converter}

Figure 3 explains the modes of operation of proposed converter for switched reluctance motor for phase excitation. Phase excitation, free-wheeling mode and de-energizing mode of three-phase SRM are illustrated in Figure 3. Current paths in respective modes of operation are explained in detailed. The respective switches placed in respective phases are operated for phase excitation mode and during deenergizing mode the diode D4 is operated for all phases de-energizing mode of operation. Figure 3(a) depicts the phase excitation mode of phase-A where switches S1 and S2 are turned ON while other switches are OFF. The current from source excites phase-A through switch S1 and S2.Figure 3(b) depicts the freewheeling mode of phase-A where the energy stored in the coil during excitation mode is freewheeled. During this mode of operation, switch S1 is only kept ON while all other switches are turned OFF. In freewheeling mode, when the switch S2 is turned OFF, the current forcefully forward biases the diode D1.

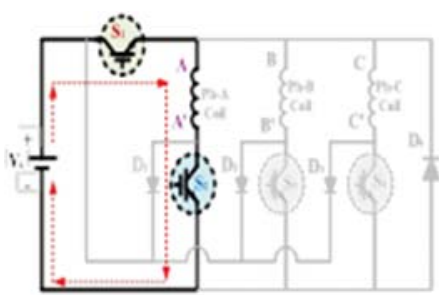

(a)

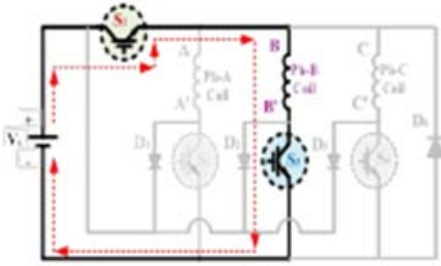

(d)

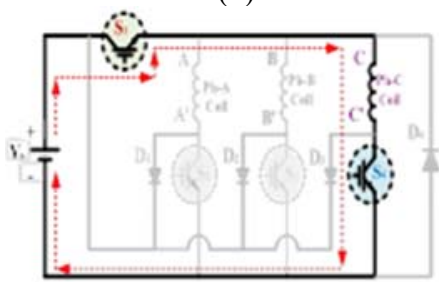

(g)

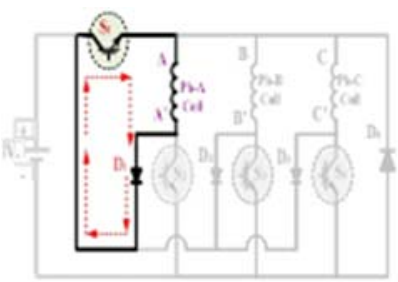

(b)

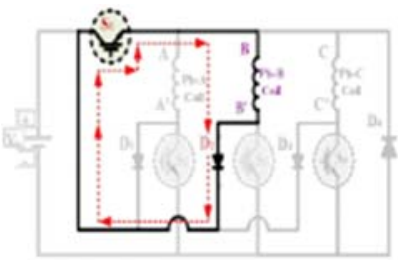

(e)

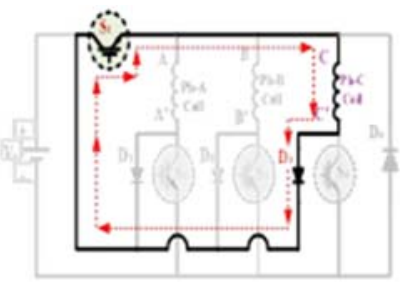

(h)

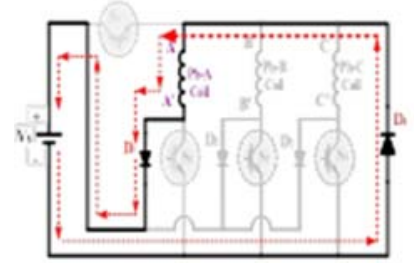

(c)

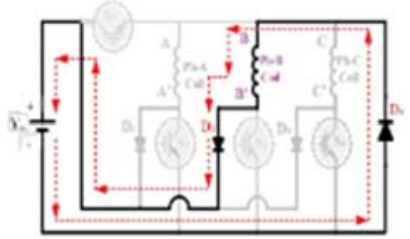

(f)

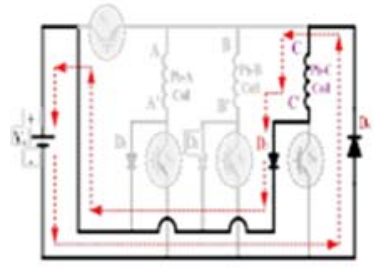

(i)

Figure 3. Modes of operation of proposed converter, (a) Operation of phase-A excitation, (b) Phase-A freewheeling mode, (c) Phase-A de-energizing mode, (d) Phase-B excitation, (e) Phase-B freewheeling mode, (f) Phase-B de-energizing mode, (g) Operation of phase- $\mathrm{C}$ excitation, (h) Phase-C freewheeling mode,

(i) Phase-C de-energizing mode. 
The freewheeling current path for phase-A is provided from the coil through diode D1 and switch S1. Figure 3(c) represents the de-energizing mode of phase-A. During this mode all the power switches are OFF and the de-energizing of phase-A is followed from coil of phase-A through diode D1 - source positive source negative - diode D4 and coil of phase-A. During this mode of operation, the energy stored in coil of phase-A charges the source and thus the name regenerative mode. Similar modes of operation for phase-B excitation, freewheeling, de-energizing is illustrated in Figures 3(d), 3(e), 3(f) respectively and phase-C excitation, freewheeling, de-energizing modes are depicted in Figures 3(g), 3(h), 3(i) respectively.

During freewheeling mode of operation of any particular phase, the switch connected in that particular respective phase turns $\mathrm{OFF}$ and forcefully turns $\mathrm{ON}$ the diode connected in respective phase. Switch S1 will be turned ON in excitation and freewheeling mode of operations while it is turned OFF in deenergizing mode. Phase de-energizing in any of the phase operations is done through diode D4 and the respective coil. The switching times of respective switches are illustrated in Figure 4. Pulse high represents the turn ON state of particular switch and pulse low represents the turn OFF state of a particular switch.

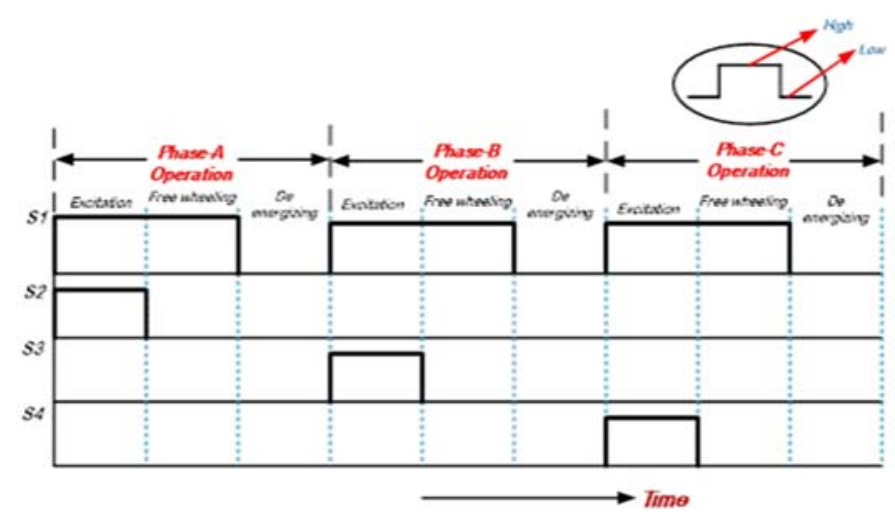

Figure 4. Switching times of switches S1, S2, S3 and S4.

\section{SPEED CONTROL OF SWITCHED RELUCTANCE MOTOR}

A large number of motors are being used for general purposes in our surroundings from house-hold equipment to machine tools in industrial facilities. Speed control of any machine is essential in any industrial application. Being widely used, SRM speed control is also an area of research for precise speed control of SRM.

\subsection{Open-loop speed control of SRM}

When the phases are excited from the converter and phase windings of SRM produce low reluctance path for rotor to align producing reluctance torque. The product of current shape extracted from the angular displacement of SRM and the magnitude yields current reference and the signal current reference when compared with actual current is sent to hysteresis controller. Gate signals are sent to switches from hysteresis controller. No speed loop is provided in open loop configuration and so preciseness of speed control is less. Figure 5 illustrates the open-loop speed control of SRM.

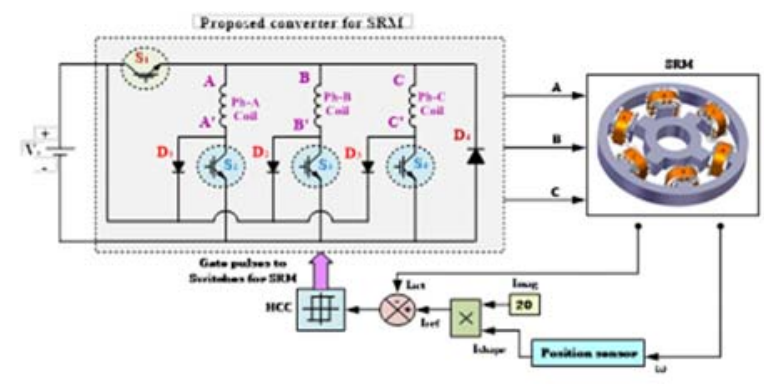

Figure 5. Open-loop speed control of SRM

Int J Pow Elec \& Dri Syst Vol. 11, No. 1, Mar $2020: 189$ - 199 


\subsection{Closed-loop speed control of SRM}

Preciseness in sped is not achieved in open-loop SRM control. The speed varies with variation in load. Industrial need of constant sped with load variations constraint fails in open-loop SRM control. A closed-loop control of SRM makes the rotor to rotate at precise speed with fine control.

Closed-loop speed control of SRM is illustrated in Figure 6. Speed feedback is not provided in open-loop but is provided in closed-loop mode. Proportional-Integral control controls the error between the actual and the set speed generating current magnitude. The product of current shape extracted from the angular displacement of SRM and the current magnitude yields current reference and the signal current reference when compared with actual current is sent to hysteresis controller. Gate signals are sent to switches from hysteresis controller. Speed loop is provided in closed loop configuration and so preciseness of speed control is high.

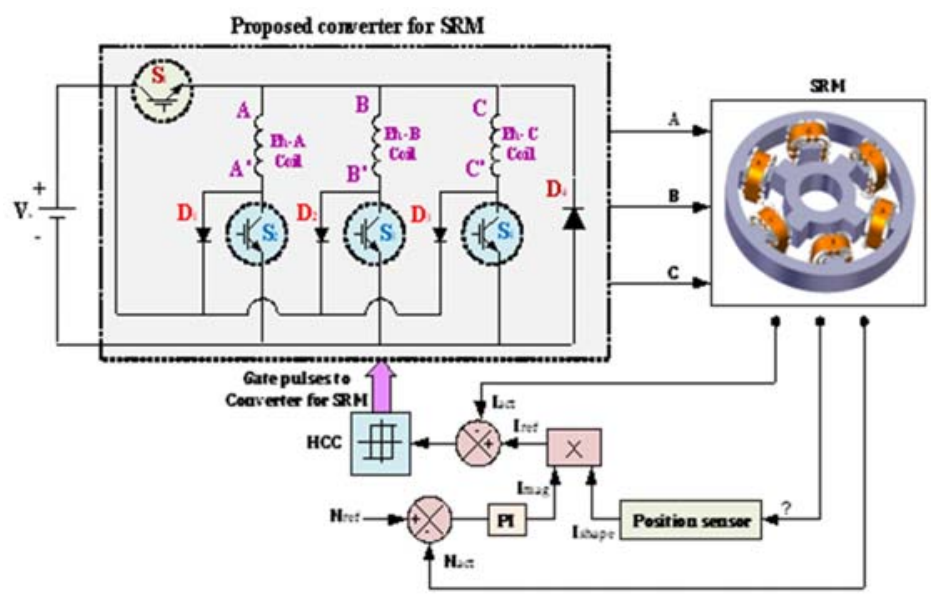

Figure 6. Closed-loop speed control of SRM

\section{RESULTS AND ANALYSIS}

\subsection{No-load srm speed control analysis with open-loop mode}

Figure 7 shows the three-phase stator currents, torque and speed of no-load switched reluctance motor running with open loop mode of operation. Three-phase stator currents with magnitude 20A having phase overlap was shown in Figure 7. SRM torque with ripple is shown in Figure. Speed of open loop noload SRM is 4600 RPM which is higher than the desired speed attains final value at $1.3 \mathrm{sec}$. As there is no control over the speed and with no-load motor condition, motor rotates with higher speeds.

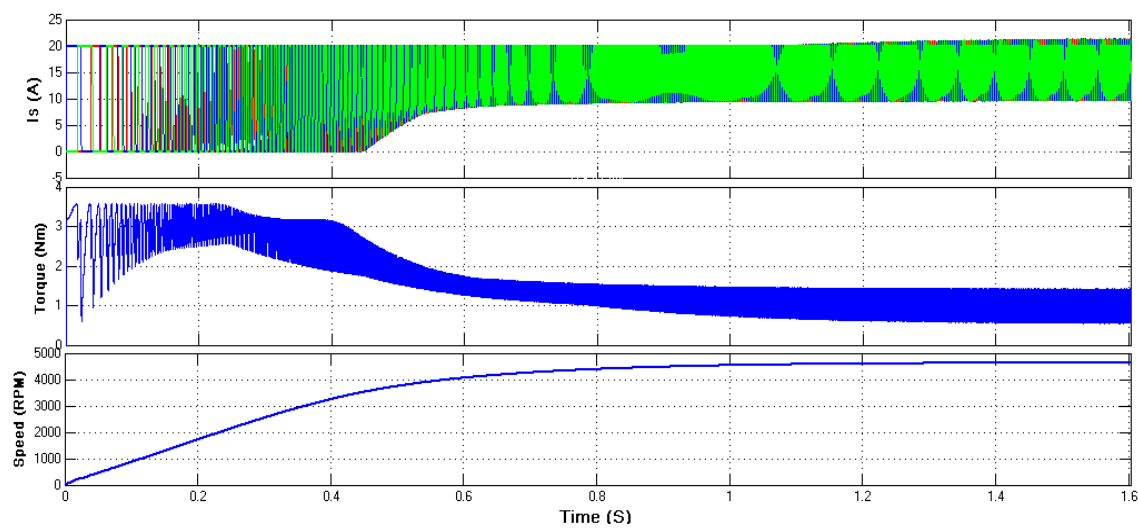

Figure 7. Switched reluctance motor characteristics three-phase stator currents, torque and speed with open loop mode of operation

Closed-loop speed control of switched reluctance motor drive fed from novel ... (Ashok Kumar Kolluru) 
Figure 8 illustrates the individual steady-state phase currents of SRM stator and each phase current of $20 \mathrm{~A}$ peak is excited to the phase windings. Three-phase flux waveform in SRM is shown in Figure 9. The peak value of flux is $0.035 \mathrm{~Wb}$ is produced when the phase is excited.

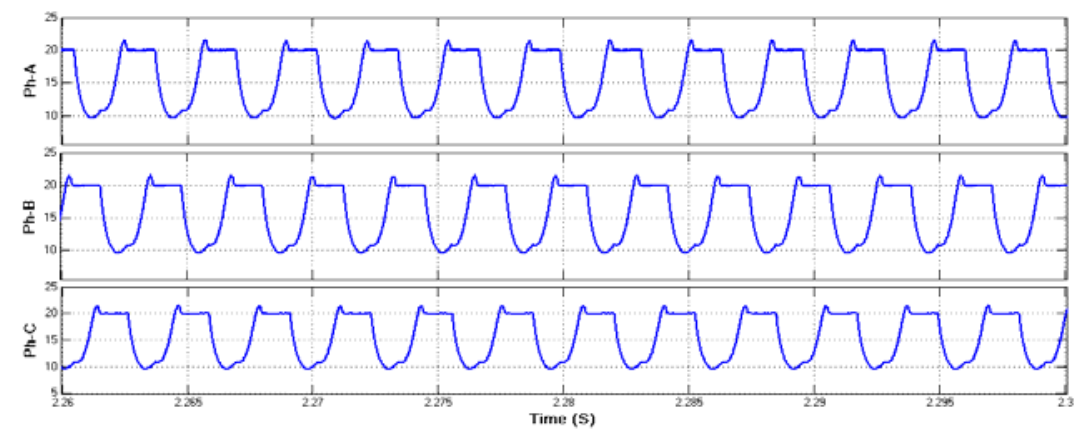

Figure 8. Individual phase currents in stator of SRM

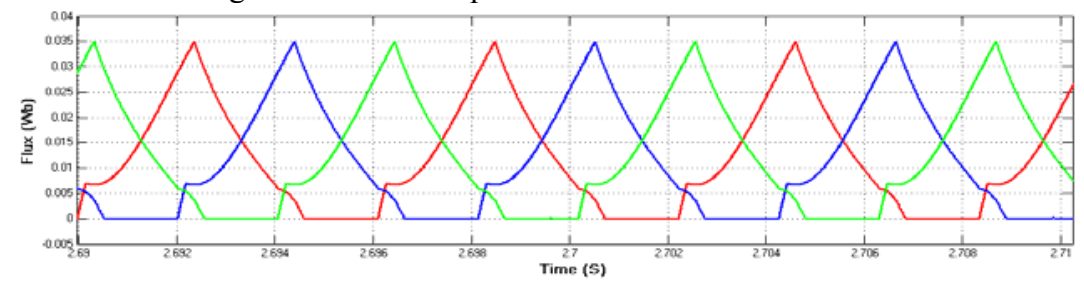

Figure 9. Three-phase flux in SRM

\subsection{No-load srm closed-loop speed control analysis with fixed speed}

Figure 10 shows the three-phase stator currents, torque and speed of no-load switched reluctance motor running with closed-loop fixed speed variation mode of operation. Three-phase stator currents with magnitude $20 \mathrm{~A}$ peak are taken by motor windings initially and after speed settles to final value, the current excitation to phase windings drops to 4A as shown in Figure 10. SRM torque with ripple is shown in Figure 10. Speed command of 2000RPM is set to SRM in closed-loop mode of operation, but the final value of 2000 RPM speed is attained at $0.24 \mathrm{sec}$ which is far earlier than in open loop mode of operation.

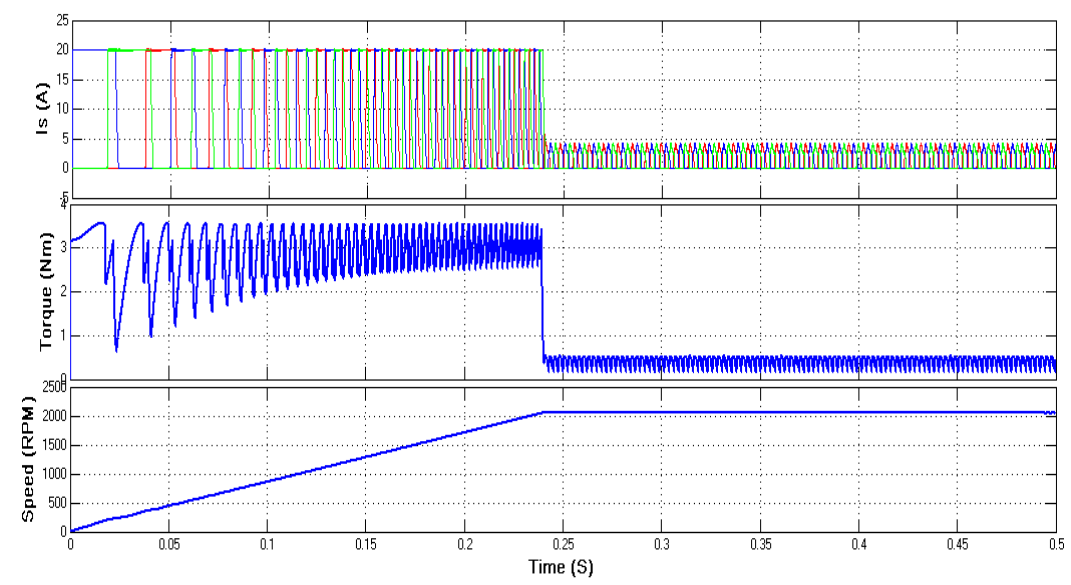

Figure 10. Switched reluctance motor characteristics three-phase stator currents, torque and speed with closed loop and fixed speed mode of operation 
Figure 11 illustrates the steady-state individual phase currents of no-load closed-loop SRM stator and each phase current of $4 \mathrm{~A}$ (steady-state) peak is excited to the phase windings. Three-phase flux waveform in SRM is shown in Figure 12.

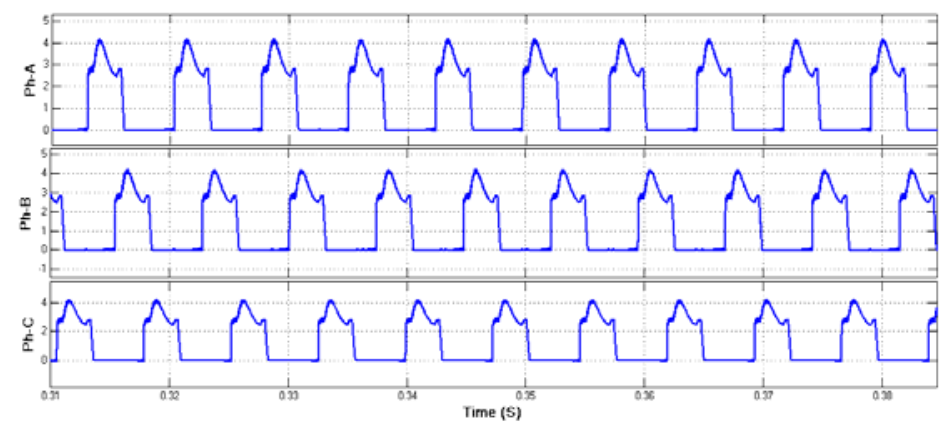

Figure 11. Individual phase currents in stator of SRM

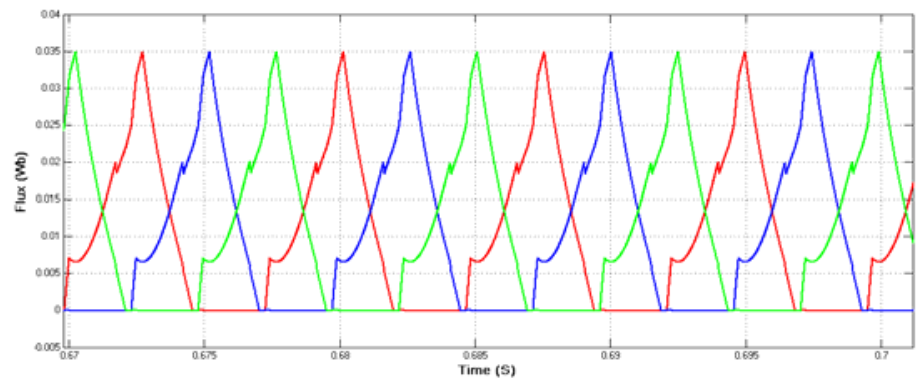

Figure 12. Three-phase flux in SRM

\subsection{Loaded srm speed control analysis with open-loop mode}

For loaded SRM condition, load torque of $2.5 \mathrm{Nm}$ is applied as load to SRM at instant 0.5 seconds. For loaded SRM condition, load torque of $2.5 \mathrm{Nm}$ is applied as load to SRM at instant 0.5 seconds. Figure 13 shows the three-phase stator currents, torque and speed of loaded switched reluctance motor running with open loop mode of operation. A three-phase stator current with magnitude of 20A was shown in Figure 13. SRM torque with ripple is shown in Figure. As load is applied at $0.5 \mathrm{sec}$, speed drops after $0.5 \mathrm{sec}$. There is no control over the speed in open loop mode and thus the speed drops after loading the SRM at 0.5 seconds.

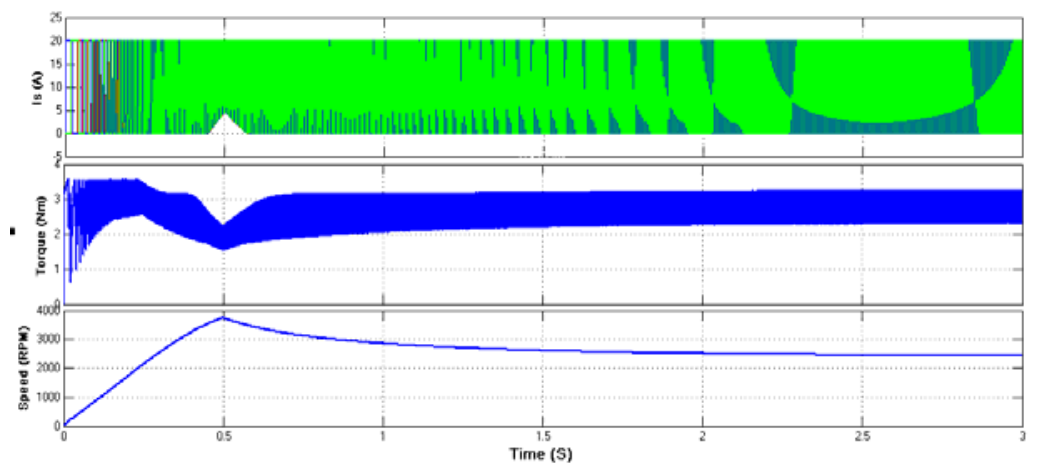

Figure 13. Switched reluctance motor characteristics three-phase stator currents, torque and speed with open loop mode of operation 
Figure 14 illustrates the individual steady-state phase currents of SRM stator and each phase current of $20 \mathrm{~A}$ peak is excited to the phase windings. Three-phase flux waveform in SRM is shown in Figure 15.

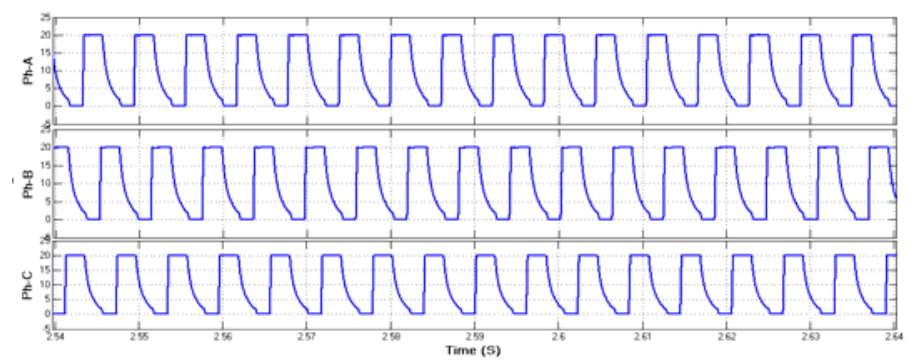

Figure 14. Individual phase currents in stator of SRM

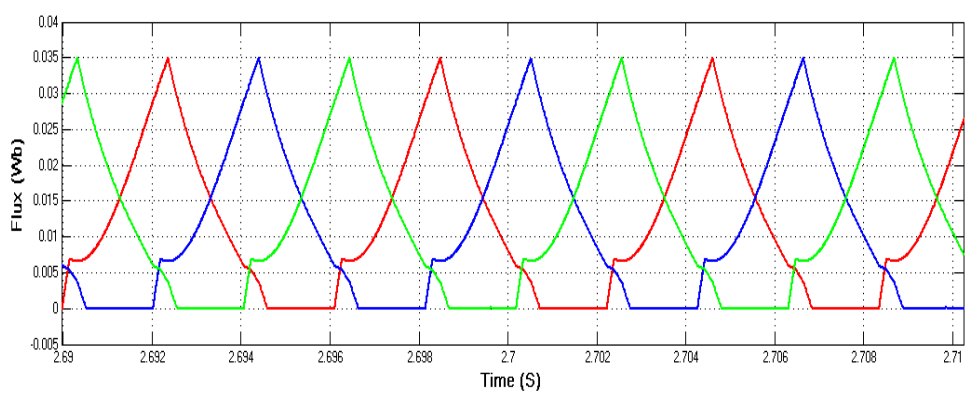

Figure 15. Three-phase flux in SRM

\subsection{Loaded srm closed-loop speed control analysis with fixed speed}

For loaded SRM condition, load torque of $2.5 \mathrm{Nm}$ is applied as load to SRM at instant 0.5 seconds. Figure 16 shows the three-phase stator currents, torque and speed of loaded switched reluctance motor running with closed-loop fixed speed variation mode of operation. A three-phase stator phase windings are excited with current of 5.5A before $(0.5 \mathrm{sec})$ loading. After loading the current raises to magnitude $20 \mathrm{~A}$ (after loading) was shown in Figure. SRM torque with ripple is shown in Figure. Torque rises after loading the SRM. Speed command of 2000RPM is set to SRM in closed-loop mode of operation but the final value of speed is attained at $0.22 \mathrm{sec}$ which is far before than open loop mode of operation. Though the SRM is loaded at $0.5 \mathrm{sec}$, the motor runs with constant speed of 2000 RPM in closed-loop mode.

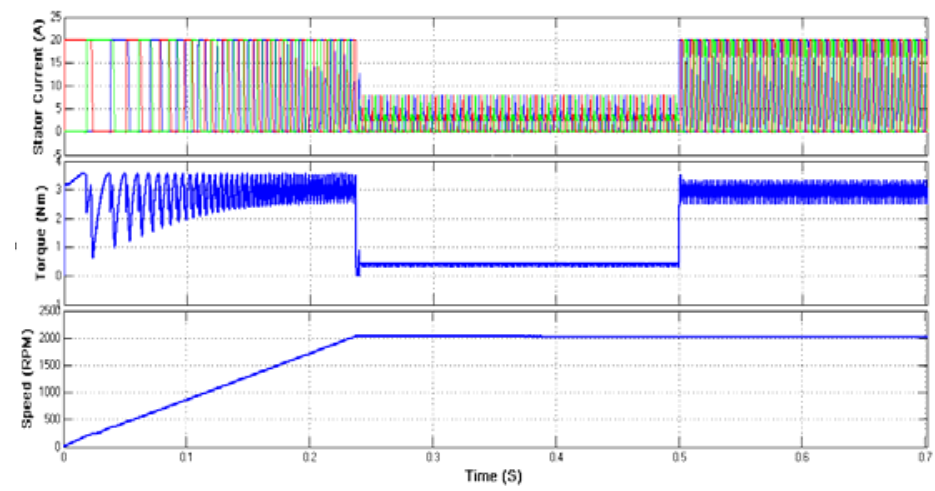

Figure 16. Switched reluctance motor characteristics three-phase stator currents, torque and speed with closed loop and fixed speed mode of operation 
Figure 17 illustrates the steady-state (after loading condition) individual phase currents of SRM stator and each phase current of $20 \mathrm{~A}$ peak is excited to the phase windings. Three-phase flux waveform in SRM is shown in Figure 18. Table 2 represents the comparative analysis between closed-loop mode and open-loop mode of SRM performance.

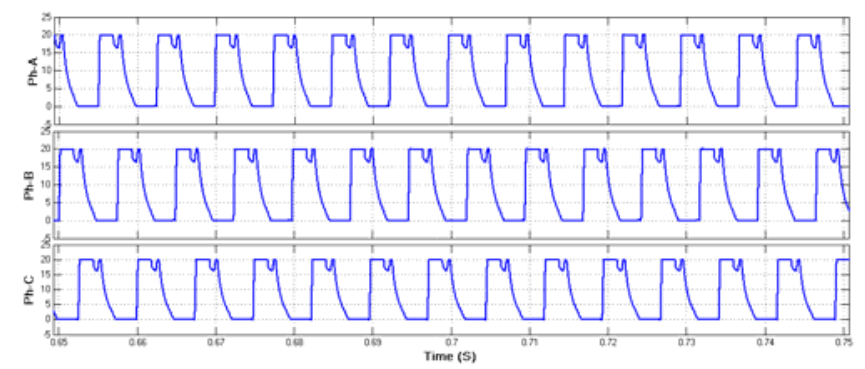

Figure 17. Individual phase currents in stator of SRM

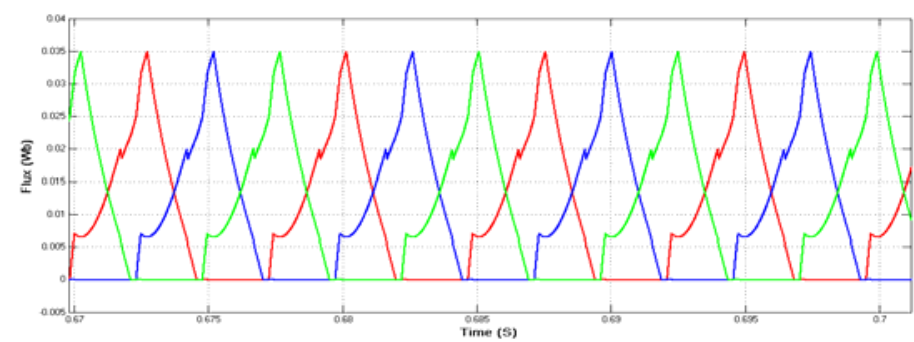

Figure 18. Three-phase flux in SRM

Table 2. Comparative analysis

\begin{tabular}{|c|c|c|c|c|c|c|c|c|c|c|c|}
\hline \multicolumn{6}{|c|}{ No-Load } & \multicolumn{6}{|c|}{ Load (Torque of $2.5 \mathrm{Nm}$ at instant $0.5 \mathrm{sec}$ ) } \\
\hline \multicolumn{3}{|c|}{ Open-loop } & \multicolumn{3}{|c|}{ Closed-Loop } & \multicolumn{3}{|c|}{ Open-loop } & \multicolumn{3}{|c|}{ Closed-Loop } \\
\hline $\begin{array}{l}\text { Stator } \\
\text { current }\end{array}$ & Torque & Speed & $\begin{array}{l}\text { Stator } \\
\text { current }\end{array}$ & Torque & Speed & $\begin{array}{c}\text { Stator } \\
\text { current }\end{array}$ & Torque & Speed & $\begin{array}{l}\text { Stator } \\
\text { current }\end{array}$ & Torque & Speed \\
\hline $\begin{array}{l}20 \mathrm{~A} \\
\text { peak }\end{array}$ & $0.8 \mathrm{Nm}$ & $\begin{array}{l}\text { 4600RPM, } \\
\text { reaches } \\
\text { final value } \\
\text { at } 1.3 \mathrm{Sec}\end{array}$ & $\begin{array}{c}4 \mathrm{~A} \\
(\mathrm{~S} . \mathrm{S})\end{array}$ & $\begin{array}{c}0.3 \mathrm{Nm} \\
\text { (S.S) }\end{array}$ & $\begin{array}{l}2000 \\
\text { RPM, } \\
\text { reaches } \\
\text { final } \\
\text { value at } \\
0.24 \\
\text { Sec }\end{array}$ & $\begin{array}{l}20 \mathrm{~A} \\
\text { peak }\end{array}$ & $2.8 \mathrm{Nm}$ & $\begin{array}{c}\text { Increases } \\
\text { to } 3800 \\
\text { RPM } \\
\text { before } \\
\text { loading } \\
\text { and drops } \\
\text { after } \\
\text { loading }\end{array}$ & $\begin{array}{c}5.5 \mathrm{~A} \\
\text { before } \\
\text { load } \\
\text { (S.S) } \\
\text { and } \\
20 \mathrm{~A} \\
\text { after } \\
\text { loading } \\
\text { (S.S) }\end{array}$ & $\begin{array}{l}0.3 \mathrm{Nm} \\
\text { (S.S) }\end{array}$ & $\begin{array}{l}2000 \\
\mathrm{RPM}, \\
\text { reaches } \\
\text { final } \\
\text { value at } \\
0.22 \\
\mathrm{Sec}\end{array}$ \\
\hline
\end{tabular}

\section{CONCLUSION}

Switched reluctance motor (SRM) is a very advanced and special electrical machine in modern day electrical applications due to its superior merits over other type of electrical machines. This paper presents the novel converter configuration with less number of switches for switched reluctance motor (SRM). The novel converter for SRM is tested for open-loop mode and closed-loop mode of operation. Further the closed-loop mode of operation of SRM with proposed novel converter is tested with fixed speed. The proposed converter for SRMT is evaluated with loaded condition and comparative analysis of no-load and loaded SRM is presented. The proposed converter works satisfactorily for loaded operations.

\section{REFERENCES}

[1] T. J. E. Miller, Ed, Switched Reluctance Motors and their Control, Lebanon, OH: Magna Physics/Oxford University Press, 1993.

[2] H. X. Wu, Switch reluctance motor theory and control technology, Beijing: Chinese Power Press, 2010.

Closed-loop speed control of switched reluctance motor drive fed from novel ... (Ashok Kumar Kolluru) 
[3] Kiruthika, D and Susitra, D, "Speed Controller of Switched Reluctance Motor,"Indian Journal of Science and Technology, pp. 1043-1048, Aug 2014.

[4] J. Dang, J. R. Mayor, J. Restrepo, S. A. Semidey, R. G. Harley and T. Habetler, "High speed SRM control considering the inductance profile of a flux-bridge rotor," IEEE International Electric Machines \& Drives Conference (IEMDC), Coeur d'Alene, ID, pp. 1593-1599,2015.

[5] M. Rafiee, E. Afjei, and A. Siadatan, "Design and construction of a new SRM sensorless driver," 21st Iranian Conference on Electrical Engineering (ICEE), Mashhad, pp. 1-5, 2013.

[6] Xudong Gao et al., "A Review of Torque Ripple Control Strategies of Switched Reluctance Motor,"International Journal of Control and Automation, vol. 8, No. 4, pp. 103-116, 2015.

[7] M. Asgar, E. Afjei, A. Siadatan, and A. Zakerolhosseini, "A new modified asymmetric bridge drive circuit switched reluctance motor,"in Proc. European Conference Circuit Theory and Design, pp. 539-542,Aug 2009.

[8] Malligunta. Kiran Kumar and Dr G R K Murthy, "Open Loop and Closed Loop Performance of Switched Reluctance Motor with Various Converter Topologies,"International Journal of Power Electronics and Drive System, Vol. 5, Special Issue on Electric Power Converter, pp. 83-92, Jul 2014.

[9] Malligunta.Kiran Kumar and Dr.O. Chandra Sekhar, "PI and Fuzzy based speed control of Switched Reluctance Motor with various Converter Topologies,"Springer: Artificial Intelligence and Evolutionary Computations in Engineering Systems, 2016.

[10] Samia M. Mahmoud et al., "Studying Different Types of Power Converters Fed Switched Reluctance Motor," International Journal of Electronics and Electrical Engineering, vol. 1, No. 4, pp 281-290, Dec, 2013.

[11] S. K. Singh and R. K. Tripathi, "Minimization of torque ripples in SRM drive using DITC for electrical vehicle application," Engineering and Systems (SCES), 2013 Students Conference on, Allahabad, pp. 1-5,2013.

[12] Srinivas Pratapgiri, "Effect of Switching Frequency in DTC Based Switched Reluctance Motor Drive,"Indonesian journal of electrical engineering and computer sciences, vol 12, No. 12, Dec 2014.

[13] Malligunta Kiran Kumar, G.R.K. Murthy, and S S Srinivas.Addala, "Open Loop and Closed Loop Performance of Switched Reluctance Motor with Various Converter Topologies,"International journal of power electronic and drive systems, vol 5(1), pp 83-92,2014.

[14] Alexander Petrushin and Maxim Tchavychalov, "Influence of Sensorless Control on the Noise of Switched Reluctance Motor Drive," International Journal of Power Electronics and Drive Systems (IJPEDS), vol. 6, No. 3, pp 433-438, 2015.

[15] Vinay Kumar and T. Kiran Kumar, M.A, "A Solar powered SRM drive for EVS using fuzzy controller,"International Journal of Innovative Technology and Exploring Engineering, vol. 8, No. 10, pp. 413-418, 2019.

[16] Dukkipati, S. Marthanda, A.V.G.A. Rajasekhar, and G.G. Kumar, M.K. "Design analysis and implementation of a three phase seven level pv \& wind based microgrid,"International Journal of Innovative Technology and Exploring Engineering, vol. 8, No. 10, pp. 4495-4498, 2019.

[17] Sundeep, D. Kumar, T.V. Kumar, M.K. Krishna, A.G, and RaviKumar, R.V.S.S.N, "Mechanical Milling Influence on Lattice Vibrational Behaviour of MoO3 -V2 O5 Composite Nanopowders,"Silicon, vol. 11, No. 3, pp. 1517 $1524,2019$.

[18] B V Rajanna, S V N L Lalitha, Ganta Joga Rao, and S K Shrivastava, "Solar photovoltaic generators with MPPT and battery storage in microgrids," in International Journal of Power Electronics and Drive Systems (IJPEDS), vol. 7(3), pp. 701-712, Sep 2016.

[19] B V Rajanna and Malligunta Kiran Kumar, "Dynamic model development for lead acid storage battery," in Indonesian Journal of Electrical Engineering and Computer Science (IJEECS), vol. 15(2), pp. 609-619, Aug 2019.

[20] B V Rajanna and Malligunta Kiran Kumar, "Comparison of one and two time constant models for lithium ion battery," in Internationl Journal of Electrical and Computer Engineering (IJECE), vol. 10, No. 1, pp. 670-680, Feb 2020.

[21] Kumar, M and Ramesh, S, "Design and Implementation of Three-Winding Coupled Inductor and Switched Capacitor-Based DC-DC Converter Fed PV-TDVR,"Journal of Circuits, Systems and Computers, vol. 28, No. 9, $1950158,2019$.

[22] Nalli, R. Subbarao, K. Ramamoorthy, and M. Kiran Kumar, M., "Sensorless control of BLDC motor using flux linkage-based Algorithm,"International Journal of Engineering and Advanced Technology, vol. 8, No. 6, pp. 15491556.

[23] D. Ravi Kishore and T. Vijay Muni, "Efficient energy management control strategy by model predictive control for standalone dc micro grids,"AIP Conference Proceedings 1992, 030012, 2018.

[24] T Vijay Muni and S V N L Lalitha, "Power Management Strategy in Solar PV System with Battery Protection Scheme,"International Journal of Innovative Technology and Exploring Engineering, vol. 8, No. 6, pp-960-964, 2019.

[25] T Vijay Muni and S V N L Lalitha, "Fast Acting MPPT Controller for Solar PV with Energy Management for DC Microgrid,"International Journal of Engineering and Advanced Technology (IJEAT), vol. 8, No. 5, pp-1539-1544, 2019.

[26] Kumar, M.K. Datta, D.V and Vijay Muni, T, "Performance enhancement of asynchronous machine with super Capacitor,"International Journal of Engineering and Advanced Technology, vol. 8, No. 4, pp. 1208-1210, 2019.

[27] Nagaraju, M and Kumar, M.K, "Analysis of series/parallel multilevel inverter with symmetrical and asymmetrical configurations,"International Journal of Power Electronics and Drive Systems, vol. 10, No. 1, pp. 300-306, 2019.

Int J Pow Elec \& Dri Syst Vol. 11, No. 1, Mar $2020: 189$ - 199 


\section{BIOGRAPHIES OF AUTHORS}

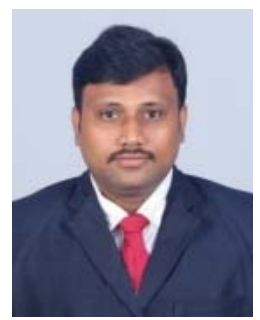

K. Ashok Kumarreceived B. Tech Degree in Electrical and Electronics Engineering from Vignan's Engineering College, JNTU, Hyderabad, India, in 2008, M.Tech. Degree in Energy Systems from JNTU College of Engineering anantapur, JNTUA University, Anantapur, India, in 2010 and pursuing Ph. D in Electrical Engineering at Koneru Lakshmaiah Education Foundation, Guntur, India. His research interest includes Switched Reluctance Machines.

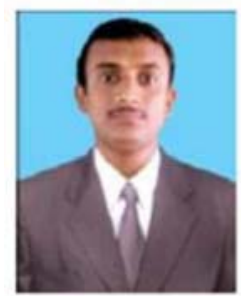

M. Kiran Kumar received B.Tech Degree in Electrical and Electronics Engineering from Gokula Krishna College of Engineering and Technology, JNTU, Hyderabad, India, in 2007, M.E. Degree in Power Electronics and Drives from Sree Sastha Institute of Engineering and Technology, Anna University, Chennai, India, in 2010 and Ph.D in Electrical Engineering at Koneru Lakshmaiah Education Foundation, Guntur, India, in 2016. His research interest includes Switched Reluctance Machines, Power Electronics and Control Systems. 